Journal of Telenursing (JOTING)

Volume 2, Nomor 1, Juni 2020

e-ISSN: 2684-8988

p-ISSN: 2684-8996

DOI: https://doi.org/10.31539/joting.v2i1.521

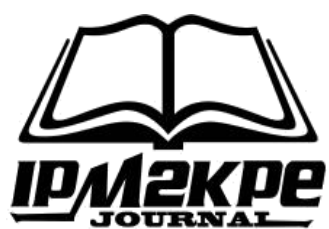

\title{
STRESS KERJA DAN KONFLIK KERJA MEMPENGARUHI KINERJA PERAWAT
}

\author{
Muhammad Amin $^{1}$, Yogi Ekwinaldo ${ }^{2}$, Yesi Novrianti ${ }^{3}$ \\ Universitas Muhammadiyah Bengkulu ${ }^{1,2,3}$ \\ maminumb@gmail.com ${ }^{1}$
}

\begin{abstract}
ABSTRAK
Penelitian ini bertujuan untuk mengetahui hubungan stress kerja dan konflik kerja terhadap kinerja perawat di ruang rawat inap Rumah Sakit Umum Daerah (RSUD) Kepahiang. Jenis Penelitian yang digunakan penelitian deskriptif analitik dengan pendekatan cross sectional. Hasil uji statistik diketahui dari 80 responden, sebanyak 39 responden $(48,8 \%)$ yang memiliki stress kerja rendah, dan $41(52,1 \%)$ responden yang memiliki stress kerja tinggi. sebanyak 43 responden $(53,8 \%)$ yang menyatakan tidak terjadi konflik, dan $37(46,2 \%)$ responden yang menyatakan terjadi konflik, hasil continuity corection untuk stress kerja $(\mathrm{P})=0,000<\alpha=0,05$ dan konflik kerja continuity corection $(\mathrm{P})=0,000<\alpha=0,05$. Simpulan, ada pengaruh yang signifikan antara stress kerja dan konflik kerja terhadap kinerja perawat di ruang rawat inap Rumah Sakit Umum Daerah (RSUD) Kepahiang.
\end{abstract}

Kata Kunci : Kinerja Perawat, Konflik Kerja, Stress Kerja

\section{ABSTRACT}

This study aims to determine the relationship between work stress and work conflict on nurses' performance in the inpatient ward of the Kepahiang Regional General Hospital. This type of research is descriptive-analytic research with a cross-sectional approach. Statistical test results from 80 respondents: as many as 39 respondents (48.8\%) have low work stress, and 41 (52.1\%) respondents have high work stress. as many as 43 respondents (53.8\%) stated there was no conflict, and 37 (46.2\%) respondents stated that there was a conflict, the results of continuity correction for work stress $(P)=0,000$ $<_{\alpha}=0.05$ and continuity work conflict correction $(P)=0.000<\alpha=0.05$. In conclusion, there is a significant influence between work stress and work conflict on the performance of nurses in the inpatient room of the Kepahiang Regional General Hospital.

Keywords: Nurse Performance, Work Conflict, Work Stress

\section{PENDAHULUAN}

Rumah sakit sebagai salah satu fasilitas pelayanan kesehatan memiliki peran yang sangat strategis dalam upaya mempercepat peningkatan derajat kesehatan masyarakat Indonesia. Salah satu profesi yang mempunyai peran penting di rumah sakit adalah keperawatan. Keperawatan adalah salah satu profesi di rumah sakit yang berperan penting dalam penyelenggaraan upaya menjaga mutu pelayanan kesehatan di rumah sakit (Yudha, 2016). Tenaga perawat yang mempunyai kedudukan penting dalam 
menghasilkan kualitas pelayanan kesehatan di rumah sakit, karena pelayanan yang diberikannya berdasarkan pendekatan bio-psiko-sosial-spiritual merupakan pelayanan yang unik dilaksanakan selama 24 jam dan berkesinambungan merupakan kelebihan tersendiri dibanding pelayanan lainnya.

World Health Organization (WHO) menyatakan stres merupakan epidemi yang menyebar ke seluruh dunia. The American Institute of Stress menyatakan bahwa penyakitpenyakit yang berhubungan dengan stres telah menyebabkan kerugian ekonomi Amerika Serikat lebih dari $\$ 100$ miliar per tahun. Survey atas pekerja tenaga perawat pelaksana di Amerika Serikat menemukan bahwa 46\% merasakan pekerjaan mereka penuh dengan stres dan $34 \%$ berpikir serius untuk keluar dari pekerjaan mereka 12 bulan sebelumnya karena stres ditempat kerja (Emita, 2014).

Profesi perawat mempunyai risiko yang sangat tinggi terkena stres, karena perawat memiliki tugas dan tanggung jawab yang sangat tinggi terhadap keselamatan nyawa manusia. Masalah-masalah yang sering dihadapi perawat diantaranya: meingkatnya stres kerja karena dipacu harus selalu maksimal dalam melayani pasien. Orang yang terkena stres kerja (dengan catatan, tidak dapat menanggulanginya) cenderung tidak produktif, secara tidak sadar malah menunjukan kebodohannya, malasmalasan, tidak efektif dan efisien dan berbagai sikap yang dapat merugikan organisasi (Karambut, 2012). Stres kerja merupakan suatu kondisi ketegangan yang menciptakan adanya ketidakseimbangan fisik dan psikis yang mempengaruhi emosi serta proses berpikir dan kondisi seorang karyawan. Konflik adalah suatu pertentangan yang terjadi antara apa yang diharapkan oleh seseorang terhadap dirinya, orang lain, organisasi dengan kenyataan apa yang diharapkannya, beban kerja yang berlebihan, perasaan susah dan ketegangan emosional yang menghambat performance individu (Almasitoh, 2011).

Kinerja merupakan suatu konstruk multidimensional yang mencakup banyak faktor yang mempengaruhinya, antara lain faktor personal atau individual, faktor kepemimpinan, faktor tim, faktor sistem, dan faktor kontekstual. Pada sistem penilaian kinerja tradisional, kinerja hanya dikaitkan dengan faktor personal, namun dalam kenyataannya, kinerja sering diakibatkan oleh faktor-faktor lain diluar faktor personal, seperti sistem, situasi, kepemimpinan, atau tim (Mahmudi, 2015).

Stres dan konflik merupakan salah satu masalah yang mungkin timbul dalam rumah sakit. Hal tersebut bisa disebabkan adanya ketidakpuasan pegawai terhadap apa yang diinginkan dan apa yang diharapkan dalam lingkungan kerja, bisa juga terjadi di luar lingkungan kerja pegawai. Stress bisa terjadi karena faktor-faktor yang menyebabkannya, atau bisa juga disebut job stressor. Stress merupakan suatu kondisi ketegangan yang mempengaruhi emosi, proses berpikir, dan kondisi mental seseorang. Menurut Sunyoto (2012) menjelaskan bahwa, konflik adalah ketidaksetujuan antara dua atau lebih anggota organisasi atau kelompok - kelompok dalam organiasasi yang timbul karena mereka harus menggunakan daya yang langka secara bersama - sama atau menjalankan kegiatan bersama - sama atau karena mereka mempunyai status, tujuan nilai - nilai dan peresepsi yang berbeda.

Berdasarkan observasi awal yang dilakukan oleh peneliti dengan melakukan wawancara terhadap 9 orang perawat yang terdiri dari masing-masing perawat yang ada di ruang penyakit dalam, kebidanan dan kandungan, bedah, neonates, anak, vapiliun, kelas 1, kelas 2, dan kelas 3, serta ICU Rumah Sakit Umum Daerah (RSUD) Kepahiang. Bahwa di ruang rawat inap RSUD Kepahiang yang terdiri dari 9 orang tersebut, 7 orang perawat mengatakan bahwa pasien yang datang ke rumah sakit sangat tinggi karena RSUD Kepahiang merupakan satu-satunya rumah sakit yang ada di 
Kabupaten Kepahiang. Rata-rata pasien yang masuk di Rumah Sakit Kepahiang yaitu 34.308 pasien per tahun dengan rata-rata jumlah pasien per hari sebanyak 93 pasien (Profil RSUD Kepahiang, 2016). Diantara 9 orang perawat tersebut, 6 orang yang mengungkapkan senioritas memang sudah terjadi pada perawat di ruang rawat Inap RSUD Kepahiang dimana senior merasa lebih berkuasa daripada junior, terjadi juga sindir-sindiran di sosmed antar perawat, adanya perawat dengan jumlah tertentu yang membentuk kelompok sehingga perawat yang tidak tergabung dalam kelompok yang terbentuk merasa terkucilkan. Dari permasalahan tersebut akan menyebabkan stress kerja perawat. Dari survey awal, terlihat masalah faktor stress, konflik kinerja perawat.

\section{METODE PENELITIAN}

Penelitian ini termasuk penelitian deskriptif analitik dengan pendekatan cross sectional, metode deskriptif digunakan untuk memperoleh data pengaruh stress kerja dan konflik kerja terhadap kinerja perawat di ruang rawat inap Rumah Sakit Umum Daerah (RSUD) Kepahiang. Waktu penelitian dilaksanakan pada bulan Maret 2017 di Rumah Sakit Umum Daerah (RSUD) Kepahiang.

Teknik pengambilan sampel yang digunakan dalam penelitian ini adalah purposive sampling, dengan kriteria sampel Perawat yang bekerja di ruang rawat inap RSUD Kepahiang, Subjek setuju untuk mengikuti penelitian, sedangkan kriteria eksklusi subyek yang berhalangan hadir saat dilakukan penelitian dan subyek menolak berpartisipasi dalam penenitian, sampel yang digunakan dalam penelitian ini sebanyak 80 responden. Instrumen dalam penelitian ini yaitu kuesioner yang ditujukan kepada sejumlah responden mengenai stress kerja dan konflik kerja terhadap kinerja perawat di ruang rawat inap Rumah Sakit Umum Daerah (RSUD) Kepahiang.

\section{HASIL PENELITIAN Analisis Univariat}

Tabel. 1

Distribusi Frekuensi

Stress Kerja Perawat

\begin{tabular}{cccc}
\hline No. & Stress Kerja & Frekuensi & Persentase $(\%)$ \\
\hline 1. & Rendah & 41 & 51,2 \\
2. & Tinggi & 39 & 48,8 \\
\hline & Total & 80 & 100.0
\end{tabular}

Sumber: Hasil Penelitian

Berdasarkan tabel 1 menunjukkan bahwa dari 80 responden, sebanyak 41 responden $(51,2 \%)$ yang memiliki stress kerja rendah, dan $39(48,8 \%)$ responden yang memiliki stress kerja tinggi.

Tabel. 2

Distribusi Frekuensi

Konflik Kerja Perawat

\begin{tabular}{cccc}
\hline No. & Konflik kerja & Frekuensi & Persentase (\%) \\
\hline 1. & Rendah & 37 & 46,2 \\
2. & Tinggi & 43 & 53,8 \\
\hline & Total & 80 & 100.0 \\
\hline
\end{tabular}

Sumber: Hasil Penelitian 
Berdasarkan tabel 2 menunjukkan bahwa dari 80 responden, mayoritas responden menyatakan konflik tinggi yaitu sebanyak $43(53,8 \%)$ responden.

Tabel. 3

Distribusi Frekuensi

Kinerja Perawat Perawat

\begin{tabular}{cccc}
\hline No. & Kinerja perawat & Frekuensi & Persentase $(\%)$ \\
\hline 1. & Rendah & 36 & 45 \\
2. & Tinggi & 44 & 55 \\
\hline & Total & 80 & 100.0 \\
\hline
\end{tabular}

Sumber: Hasil Penelitian

Berdasarkan tabel 3 menunjukkan bahwa dari 80 responden, mayoritas responden menyatakan konflik tinggi yaitu sebanyak 44 (55\%) responden.

\section{Analisis Bivariat}

Tabel. 4

Hubungan Stress Kerja terhadap

Kinerja Perawat

\begin{tabular}{|c|c|c|c|c|c|c|c|}
\hline \multirow{3}{*}{ Stress Kerja } & \multicolumn{6}{|c|}{ Kinerja Perawat } & \multirow{2}{*}{ Nilai $\mathrm{P}$} \\
\hline & \multicolumn{2}{|c|}{ Rendah } & \multicolumn{2}{|c|}{ Tinggi } & \multicolumn{2}{|c|}{ Total } & \\
\hline & $\mathrm{n}$ & $\%$ & $\mathrm{n}$ & $\%$ & $\mathrm{n}$ & $\%$ & \multirow{4}{*}{0,000} \\
\hline Rendah & 35 & 85,4 & 6 & 14,6 & 41 & 100 & \\
\hline Tinggi & 1 & 2,6 & 38 & 97,4 & 39 & 100 & \\
\hline Total & 36 & 100 & 44 & 100 & 80 & 100 & \\
\hline
\end{tabular}

Sumber : Hasil Penelitian

Berdasarkan tabel 4 dapat dilihat bahwa hasil continuity corection $(\mathrm{P})=0,000<\alpha$ $=0,05$ maka ada pengaruh yang signifikan antara stress kerja terhadap kinerja perawat di ruang rawat inap Rumah Sakit Umum Daerah (RSUD) Kepahiang.

Tabel. 5

Hubungan Konflik Kerja terhadap

Kinerja Perawat

\begin{tabular}{|c|c|c|c|c|c|c|c|}
\hline \multirow{3}{*}{ Konflik kerja } & \multicolumn{6}{|c|}{ Kinerja Perawat } & \multirow[t]{3}{*}{ Nilai $\mathrm{P}$} \\
\hline & \multicolumn{2}{|c|}{ Rendah } & \multicolumn{2}{|c|}{ Tinggi } & \multicolumn{2}{|c|}{ Total } & \\
\hline & $\mathrm{n}$ & $\%$ & $\mathrm{n}$ & $\%$ & $\mathrm{n}$ & $\%$ & \\
\hline Rendah & 33 & 89,2 & 4 & 10,8 & 37 & 100 & 0,000 \\
\hline Tinggi & 3 & 7 & 40 & 93 & 43 & 100 & \\
\hline Total & 36 & 100 & 44 & 100 & 80 & 100 & \\
\hline
\end{tabular}

Berdasarkan tabel 5 menunjukkan bahwa hasil uji continuity corection $(\mathrm{P})=0,000$ $<\alpha=0,05$ maka ada pengaruh yang signifikan antara konflik kerja terhadap kinerja perawat di ruang rawat inap Rumah Sakit Umum Daerah (RSUD) Kepahiang. 


\section{PEMBAHASAN}

\section{Stress Kerja Perawat}

Hasil penelitian menunjukkan dari 80 responden, sebanyak 41 responden $(51,2 \%)$ yang memiliki stress kerja rendah, dan $39(48,8 \%)$ responden yang memiliki stress kerja tinggi. Hasil penelitian yang dilakukan Ismafiaty (2011) Responden terbanyak yang mengalami stres ringan sebanyak 7 orang (14\%). Usia dewasa pertengahan dimana merupakan usia produktif bagi seseorang yang cenderung untuk bekerja lebih keras sehingga kemungkinan untuk mendapatkan stres sangat tinggi. Hal tersebut sejalan dengan pendapat (Hawari, 2011).

Penelitian yang dilakukan The National Institute Occupational Safety and Health (NIOSH) menunjukkan bahwa pekerjaan-pekerjaan yang berhubungan dengan Rumah Sakit atau kesehatan memiliki kecenderungan tinggi untuk terkena stres atau depresi. Sedangkan American National Association for Occupational Health (ANAOH) menempatkan kejadian stres kerja pada perawat berada diurutan paling atas pada empat puluh pertama kasus stres kerja pada pekerja (Rahman, 2010). Hal tersebut adalah sumber-sumber utama yang menyebabkan stres kerja perawat dan hal-hal ini yang peneliti jumpai di Ruang Rawat Inap RSUD Kabupaten Kepahiang. Ruang rawat inap khusus merupakan ruangan yang selalu dipenuhi pasien-pasien dan perlu penanganan yang tinggi. Sehingga diperlukan kesigapan dan kecepatan perawat dalam menangani pasien-pasien-pasien tersebut.

Tanda-tanda atau indikator stress yang dialami perawat di ruang rawat inap antara lain sebagian besar perawat mengalami keluhan seperti bangun pagi tidak segar atau lebih, lekas capek pada saat menjelang sore, lekas lelah sesudah makan, tidak dapat rileks, lambung atau perut tidak nyaman, jantung berdebar dan otot kaku. Hal ini karena cadangan tenaga memadai. Hasil penelitian ini sejalan dengan penelitian yang dilakukan Emita (2014) bahwa sebagian besar responden mengalami stres kerja berat $(56,7 \%)$.

Hasil penelitian Persatuan Perawat Nasional Indonesia pada tahun 2006 menunjukkan 50,9\% perawat Indonesia pernah mengalami stres kerja, dengan gejala sering pusing, kurang ramah, merasa lelah, kurang istirahat akibat beban kerja berat serta penghasilan tidak memadai (sukmaretnawati, 2013). Menurut data Kementerian Kesehatan RI tahun 2014 jumlah perawat di Indonesia mencapai 237.181 orang, dengan demikian angka kejadian stres kerja pada perawat cukup besar.

\section{Konflik Kerja Perawat}

Hasil penelitian menunjukkan bahwa dari 80responden, sebanyak 37 responden (46,2 \%) yang menyatakan terjadi konflik dengan kategori rendah, dan 43 (53,8\%) responden yang menyatakan konflik tinggi. Adapun konflik yang terjadi pada perawat di ruang rawat inap RSUD Kepahiang menurunkan kinerja karyawan, sementara menurunnya kinerja karyawan bisa memberi dampak pada meningkatnya keinginan untuk keluar, meningkatnya absensi, dan menurunnya komitmen organisasi.

Stres dan konflik merupakan salah satu masalah yang mungkin timbul dalam rumah sakit. Hal tersebut bisa disebabkan adanya ketidakpuasan pegawai terhadap apa yang diinginkan dan apa yang diharapkan dalam lingkungan kerja, bisa juga terjadi di luar lingkungan kerja pegawai. Stress bisa terjadi karena faktor-faktor yang menyebabkannya, atau bisa juga disebut job stressor. Stress merupakan suatu kondisi ketegangan yang mempengaruhi emosi, proses berpikir, dan kondisi mental seseorang. Menurut Sunyoto (2012) menjelaskan bahwa, konflik adalah ketidaksetujuan antara dua atau lebih anggota organisasi atau kelompok - kelompok dalam organiasasi yang timbul 
karena mereka harus menggunakan daya yang langka secara bersama - sama atau menjalankan kegiatan bersama - sama atau karena mereka mempunyai status, tujuan nilai - nilai dan peresepsi yang berbeda.

Konflik peran ini yang mesti diperhatikan sebagai faktor pembentuk terjadinya stress di tempat kerja, meskipun ada faktor dari luar organisasi seharusnya organisasi juga memperhatikan hal ini. Karena pengaruh terhadap anggota yang bekerja dalam organisasi tersebut meningkatkan pekerjaan yang dilakukan perawat memicu stress, karena perawat berhubungan langsung dengan dengan tekanan dari supervisor (kepala ruang, harus mampu menangani keluhan pasien dan keluarganya, menghadapi pasien dalam kegawatan, perawat juga dituntut melaksanakan standar pelayanan prima, sikap menjadi patner dokter dalam setiap kasus (baik penyakit menular maupun tidak menular) dan melaksanakan advise dokter setiap saat.

\section{Kinerja Perawat}

Hasil penelitian mengenai kinerja perawat di ruang rawat inap khusus RSUD Kepahinag diketahui bahwa dari 80 responden, sebanyak 36 responden (45\%) yang menyatakan kinerja dengan kategori rendah, dan 44 (55\%) responden yang menyatakan kinerja dengan kategori tinggi. Keadaan ini disebabkan karena beberapa faktor yaitu beratnya beban kerja perawat misalnya merawat pasien krtis terlalu banyak, perawat harus selalu di depan pasien karena membutuhkan pengawasan khusus dan kekurangan tenaga, sehingga faktor-faktor tersebut menjadikan perawat tidak cukup waktu untuk mengisi dokumentasi keperawatan dengan baik.

Kinerja merupakan suatu konstruk multidimensional yang mencakup banyak faktor yang mempengaruhinya, antara lain faktor personal atau individual, faktor kepemimpinan, faktor tim, faktor sistem, dan faktor kontekstual. Pada sistem penilaian kinerja tradisional, kinerja hanya dikaitkan dengan faktor personal, namun dalam kenyataannya, kinerja sering diakibatkan oleh faktor-faktor lain diluar faktor personal, seperti sistem, situasi, kepemimpinan, atau tim (Mahmudi, 2015).

Dari indikator pengkajian menunjukkan bahwa secara garis besar sudah melaksanakan pengkajian sesuai standar namun masih ditemukan perawat yang tidak pernah dan hanya kadang-kadang melaksanakan pengkajian dan mengkonfirmasikan kepada ketua tim keperawatan sebagai penganggung jawab tentang data pasien. Dari indikator diagnosa keperawatan yang perlu mendapat perhatian mengenai masalah telah dirumuskan tidak pernah mengacu pada pengelompokkan diagnosis keperawatan untuk setiap pasien. Dari indikator perencanaan dan pelaksanaan sebagian besar sudah dilaksanakan sesuai standar. Semua indikator kinerja mengenai pendokumentasian asuhan keperawatan yang perlu mendapat perhatian serius adalah mengenai evaluasi keperawatan yang hanya mencapai 59,2\%, sehingga dapat dikatakan bahwa sebagian besarperawat belum mengevaluasi dan menyesuaikan rencana keperawatan sesuai kebutuhan seluruh pasien dan tidak pernah melakukan evaluasi secara terus menerus. Dari hasil wawancara hal ini disebabkan perawat tidak ada waktu untuk melakukan evaluasi, karena banyaknya dokuemntasi keperawatan yang harus ditulis. Hasil penelitian ini mendukung penelitian menemukan sebagian besar kinerja perawat dalam kategori cukup/sedang 73,92\% (Mulyana, 2013). Hasil penelitian juga mendukung penelitian (Kristianti, 2016) yang menemukan ada hubungan stres kerja dengan kinerja perawat dalam asuhan keperawatan di Ruang Perawatan Khusus RSUD dr. Soediran Mangun Sumarso Wonogiri. 


\section{Hubungan Stres Kerja dengan Kinerja Perawat di Ruang Rawat Inap RSUD Kepahiang}

Hasil continuity corection $(\mathrm{P})=0,000<\alpha=0,05$ maka ada pengaruh yang signifikan antara stress kerja terhadap kinerja perawat di ruang rawat inap Rumah Sakit Umum Daerah (RSUD) Kepahiang. Terdapat banyak sumber yang mempengaruhi stres kerja pada perawat yang bisa mengakibatkan turunnya kualitas atau kinerja seorang perawat dalam melaksanakan tugasnya, salah satunya dalam melaksanakan standar asuhan keperawatan, profesi perawat mempunyai risiko yang sangat tinggi terkena stres, orang yang terkena stres kerja cenderung kurang produktif, malas-malasan bekerja tidak efektif dan efisien serta melakukan berbagai sikap yang dapat merugikan organisasi, Hasil penelitian dari menunjukkan bahwa ada hubungan yang cukup kuat antara stres kerja dengan kinerja perawat di RSUD dr. Soediran Mangun Sumarso Wonogiri (Kristianti, 2016).

Stres kerja merupakan suatu kondisi ketegangan yang menciptakan adanya ketidakseimbangan fisik dan psikis yang mempengaruhi emosi serta proses berpikir dan kondisi seorang karyawan. Konflik adalah suatu pertentangan yang terjadi antara apa yang diharapkan oleh seseorang terhadap dirinya, orang lain, organisasi dengan kenyataan apa yang diharapkannya, Stres merupakan beban kerja yang berlebihan, perasaan susah dan ketegangan emosional yang menghambat performance individu (Almasitoh, 2011).

Hasil penelitian menunjukkan bahwa penyebab stres kerja perawat adalah beban kerja yang berlebihan, lingkungan kerja yang beresiko, waktu pembedahan yang menekan, hal tersebut menunjukan stres yang berhubungan dengan aktivitas dan lingkungan fisik.Sedangkan hubungan dengan dokter dan teman sejawat karena komunikasi buruk dapat menyebabkan stres yang berhubungan dengan mental (Azizpour, 2013). Bukti menunjukkan bahwa stres dapat berpengaruh positif maupun negatif terhadap kinerja karyawan. Bagi banyak karyawan, tingkatan stres yang rendah hingga menengah memungkinkan karyawan untuk menunaikan pekerjaan secara lebih baik dengan cara meningkatkan intensitas kerja, kesiagaan, dan kemampuan beraksi karyawan (Robbins, 2011).

Hubungan kerja merupakan hubungan kerjasama antara semua pihak yang berada dalam proses produksi di suatu tempat, Hubungan kerja yang terjalin diantara semua pihak yang ada di perusahaan sudah tentu hubungan kerja yang bertujuan untuk memajukan perusahaan. Kerja sama yang terjalin diantara rekan kerja bisa berupa kerja sama tim yang mana merupakan perkumpulan dari berbagai macam pola pikir karyawan menjadi satu sehingga terdapat pemahaman yang berbeda. Karyawan yang berasa dari usia dan demografi yang berbeda sudah tentu akan menimbulkan perbedaan pendapat dan berujung pada konflik yang dapat mempengaruhi kinerja karyawan (Tajvar, 2013).

Penelitian yang dilakukan Hafzah tahun 2012 dilihat dari uji chi-square didapatkan nilai $\mathrm{p}=0,000<0,05$ dan koefisien $\mathrm{r}=0,682$ menunjukkan hubungan yang kuat, penelitian ini bersifat positif, stres kerja perawat mayoritas kategori sedang $(42,2 \%)$, kinerja perawat mayoritas cukup $(48,9 \%)$ dan hasil penelitian ini menyatakan ada hubungan yang signifikan antara stres kerja (Hafsah, 2012). 


\section{Hubungan Konflik Kerja dengan Kinerja Perawat di Ruang Rawat Inap RSUD Kepahiang}

Berdasarkan hasil diatas dapat disimpulkan bahwa ada pengaruh yangditimbulkan dari tingkat konflik terhadap kinerja perawat di ruang rawat inap RSUD Kepahiang.Tingkat konflik yang dialami perawat adalah tingkat rendah dan prestasi kerja perawat pada tingkat tinggi.Secara keseluruhan dapat dikatakan bahwa perawat di RSUD Kepahiang masih sedikit memiliki kreativitas, inovasi dan adaptasi pada lingkungan, masih kurang terbuka pada perubahan.

Hal ini sesuai dengan penelitian yang dilakukan oleh Putri, Kasmiruddin (2014) pengaruh yang ditimbulkan antara tingkat konflik dengan prestasi kerja berdasarkan dari hasil perhitungan menggunakan uji chi square menunjukkan bahwa diperoleh chi kuadrat hitung lebih besar dari chi kuadrat tabel yaitu 10,36>9,488. Artinya ada pengaruh yang signifikan antara tingkat konflik dengankinerja perawat pada RSJ Tampan Pekanbaru.

Data diatas juga menunjukkan bahwa dari 34 orang yang merasa pada tingkat konflik yang rendah, ada sebanyak 17 orang yang menyatakan prestasi kerja mereka pada tingkat yang tinggi dibandingkan dengan kategori yang lain. Hal ini juga berlaku untuk tingkat konflik pada tingkat sedang. Bahwa dari sebanyak 30 orang, yang menjawab pada prestasi kerja yang tinggi ada sebanyak 14 orang dibandingkan pada kategori lain. Sedangkan untuk tingkat konflik yang tinggi dari sebanyak 24 orang, yang menjawab prestasi kerja tinggi ada 11 orang dan yang menjawab prestasi kerja sedang ada 13 orang (Putri \& Kasmiruddin, 2014).

Penelitian yang sebelumnya juga dilakukan oleh Rosita (2016) tentang pengaruh konfik kerja dan stress kerja, hasil analisis korelasi yang menunjukkan konflik kerja, stress kerja, secara silmutan memiliki pengaruh yang signifikan terhadap kinerja.

Menurut Sunyoto (2012) menjelaskan bahwa, konflik adalah ketidaksetujuan antara dua atau lebih anggota organisasi atau kelompok - kelompok dalam organiasasi yang timbul karena mereka harus menggunakan daya yang langka secara bersama sama atau menjalankan kegiatan bersama - sama atau karena mereka mempunyai status, tujuan nilai - nilai dan peresepsi yang berbeda.

Selanjutnya Putri \& Kasmiruddin (2014) menjelaskan bahwa tingkat konflik yang dialami perawat adalah tingkat rendah dan prestasi kerja perawat pada tingkat tinggi. Secara keseluruhan dapat dikatakan bahwa perawat RSJ Tampan Pekanbaru masih sedikit memiliki kreativitas, inovasi dan adaptasi pada lingkungan, masih kurang terbuka pada perubahan. Secara teoritis menyatakan bahwa tingkat konflik yang sedang dan prestasi kerja yang tinggi adalah hubungan yang optimal. Untuk itu bagi pihak RSJ Tampan Pekanbaru, tingkat konflik yang dialami oleh perawat seharusnya berada pada tingkat sedang. Hal ini juga untuk meningkatkan kinerja organisasi secara keseluruhan. Sedangkan untuk prestasi kerja perawat agar tetap dapat dijaga pada tingkat yang tinggi. Ini juga untuk tetap menjaga kualitas dari bentuk pelayanan yang diberikan oleh perawat itu sendiri.

\section{SIMPULAN}

Terdapat hubungan yang signifikan antara stress kerja terhadap kinerja perawat di ruang rawat inap Rumah Sakit Umum Daerah (RSUD) Kepahiang. Terdapat hubungan yang signifikan antara konflik kerja terhadap kinerja perawat di ruang rawat inap Rumah Sakit Umum Daerah (RSUD) Kepahiang. 


\section{SARAN}

Bagi tempat penelitian, diharapkan pihak RSUD kepahiang untuk mencari solusi penyelesaian stess dan konflik kerjayang terjadi pada perawat di ruang rawat inap RSUD Kepahiang dengan meningkatkan koordinasi dan komunikasi antar perawat.

Bagi responden, diharapkan hasil penelitian ini dapat dijadikan sebagai bahan acuan dan evaluasi bagi perawat RSUD Kepahiang. Bagi Peneliti lain agar dapat meneliti lebih lanjut tentang faktor yang mempengaruhi kinerja perawat.

\section{DAFTAR PUSTAKA}

Almasitoh, U. H. (2011). Stres Kerja Ditinjau dari Konflik Peran Ganda dan Dukungan Sosial Pada Perawat. Psikoislamika - Jurnal Psikologi Islam

Azizpour, Y. (2013). A Survey the Associated Factors of Stress among Operating Room Personnel. Thrita journal Of Medical Science, 2(3), 19- 23

Dewi, D. K., \& Kasmiruddin, K. (2014). Pengaruh Tingkat Konflik terhadap Prestasi Kerja Perawat Rumah Sakit (Kasus Rumah Sakit Jiwa Tampan Pekanbaru). Jurnal Online Mahasiswa Fakultas Ilmu Sosial dan Ilmu Politik Universitas Riau,1(2), 1-13

Emita, S. (2014). Hubungan antara Stres Kerja dengan Kinerja Perawat Pelaksana di Ruang Rawat Inap Rsud Dr. Achmad Mochtar Bukittinggi. Universitas Muhammadiyah Sumatera Barat

Hafsah, J. (2013). Hubungan antara Stres Kerja dengan Kinerja Perawat Pelaksana di Instalasi Rawat Inap RSUD Kota Dumai Tahun 2012. Medan: Universitas Sumatera Utara

Hawari, D. (2011). Manajemen Stres Cemas dan Depresi. Jakarta : FKUI

Ismafiaty, I. (2011). Hubungan antara Strategi Koping dan Karakteristik Perawat dengan Stres Kerja di Ruang Perawatan Intensif Rumah Sakit Dustira Cimahi. Skripsi

Karambut, K. (2012). Analisis Pengaruh Kecerdasan Emosional, Stres Kerja dan Kepuasan Kerja Hal Komitmen Organisasional. Fakultas Ekonomi dan Bisnis. Universitas Brawijaya

Kristianti, E. (2016). Hubungan Stres Kerja dengan Kinerja Perawat dalam Pendokumentasian Asuhan Keperawatan di Ruang Perawatan Khusus RSUD dr. Soediran Mangun Sumarso Wonogiri, Surakarta: Stikes Kusuma Husada

Mahmudi, M. (2015). Manajemen Kinerja Sektor Publik, Edisi 3. Yogyakarta: UPP STIM YKPN

Mulyana, H. (2013). Faktor yang Berpengaruh terhadap Kinerja Perawat di Rumah Sakit Tingkat III 16.06.01 Ambon. Jurnal AKK, 2(1), 18-26. journal.unhas.ac.id/index.php

Profil RSUD Kepahiang, (2016) Kepahiang : Dinas Kesehatan Kabupaten Kepahiang 2016

Rahman, F. (2010). Strategi Coping Perawat Rumah Sakit Jiwa Daerah Surakarta. Skripsi. Fakultas Psikologi Universitas Muhammadiyah Surakarta

Robbins, S. P. (2011). Perilaku Organisasi. Edisi Duabelas, Jakarta: Salemba Empat

Rosita, S. (2012). Pengaruh Konflik Peran Ganda dan Stress Kerja terhadap Kinerja Dosen Wanita di Fakultas Ekonomi Universitas Jambi

Sukmaretnawati C., Rosa, E. M., \& Wahyuningsih, S. H (2013). Pengaruh Stres Kerja Perawat terhadap Perilaku Implementasi Patient Safety di IGD RS Panembahan Senopati Bantul. Yogyakarta: Universitas Muhammadiyah 
Sunyoto, D. (2012). Manajemen Sumber Daya Manusia. Yogyakarta : CAPS

Tajvar, A., Gebraeil, N. S., \& Amin, G. (2013). Occupational Stress and Mental Health among Nurses in a Medical Intensive Care Unit of a General Hospital in Bandar Abbas in 2013. Electronic Physician, 7(3), 1108-1113. DOI: 10.14661/2015.1108-1113

Yudha, P. M. (2016). Analisis Kualitas Kehidupan Kerja Perawat Pelaksana di Rumah Sakit Putri Hijau Medan. Jurnal Jumantik, 1(1), 147-154 